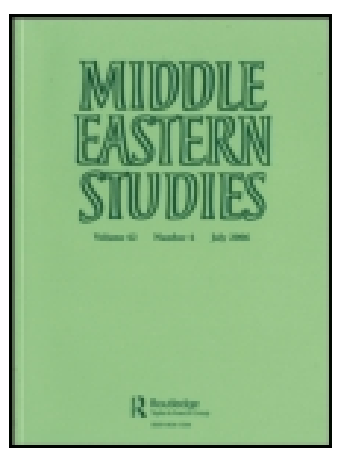

Middle Eastern Studies

\title{
A Scion of the Crimean Khans in the Crimean War: The Allied Powers and the Question of the Future of the Crimea
}

Dr Hakan Kirimli

To cite this article: Dr Hakan Kirimli (2013) A Scion of the Crimean Khans in the Crimean War: The Allied Powers and the Question of the Future of the Crimea, Middle Eastern Studies, 49:2, 191-220, DOI: 10.1080/00263206.2012.759104

To link to this article: http://dx.doi.org/10.1080/00263206.2012.759104

曲 Published online: 25 Mar 2013.

Submit your article to this journal $\widetilde{ }$

Џll Article views: 353

Q View related articles $₫$ 


\title{
A Scion of the Crimean Khans in the Crimean War: The Allied Powers and the Question of the Future of the Crimea
}

\author{
HAKAN KIRIMLI*
}

The great political crisis which had been troubling the European powers for some time culminated with the landing of the Allied (i.e. British, French, and Ottoman) troops in the Crimea, then part of the Russian empire, in September 1854, thereby starting what was to be called the 'Crimean War'. Though the Ottoman and Russian empires had already been fighting for a year, the military involvement of the British and French (as well as the political stance of Austria) turned the conflict into a 'global' one. The fighting on the Crimean peninsula was far more rapidly and thoroughly covered by the press and monitored by the public than the previous wars, thanks to the presence of war correspondents on the very frontline and the introduction of remarkable innovations, such as the telegraph, photography, and other novel products of 'advanced technology'. Thus, the relatively small and seemingly unnoticed Crimean peninsula instantly became the focus of worldwide attention. Any kind of information about the Crimea, not only the news about the present occurrences there, but also general narratives on the history, nature, and inhabitants of the land were in high public demand. Not surprisingly, earlier travelling accounts of the Russian empire, with specific attention to the Crimea, were widely published or republished in the West.

As a matter of fact, the Crimea had the features of being far more than an ordinary province of the vast Russian empire and was by no means devoid of a particular identity. The Crimea had been annexed to Russia only in 1783, just 70 years before the Crimean War, as a result of long wars. It was a land with a deep historical tradition of independent statehood and large number of non-Russian and non-Christian (overwhelmingly Muslim) indigenous inhabitants. At the beginning of the war, Turkic and Muslim Crimean Tatars, the native people of the peninsula, still constituted the absolute majority of the population of the Crimea. ${ }^{1}$ Actually, the Crimean Tatars used to have their own statehood, i.e. the Crimean Khanate, comprising the Crimea and the large steppes on the mainland, from the early fifteenth century up to 1783 (not to mention the earlier political formations they had been successors to).

*Bilkent University, International Relations, Ankara, 06800 Turkey. E-mail: hakankirimli @yahoo.co 
The Crimean Khanate was a direct successor to the empire of the Golden Horde. The ruling dynasty of the Crimean Khanate was the house of Gerays. It was believed that Gerays had a direct lineage to Chinghis Khan through his son Juji. When the central power in the Golden Horde began to shatter and disintegrate during the first half of the fifteenth century, the Chinghiside prince Giyaseddin and his son Hacı Geray, having been based on the Crimean peninsula, established themselves in the southern parts of the Golden Horde to claim the throne of the Great Khan. Actually, the body politic thus formed became a state in its own right, which was called the Crimean Khanate, though its rulers never renounced their claims over the whole of the Golden Horde terrain until the bitter end. That particular Chinghiside dynasty descending from Hac1 Geray was named the Geray dynasty after its founder's cognomen. For some three-and-a-half centuries, the Gerays incontestably ruled the Crimean Khanate. The house of Geray was more than a dynasty with an unchallengeable right to rule the Crimean Khanate; it was one of the most respected Islamic dynasties whose legitimacy was beyond question, so much so that it was even commonly argued that, in the case of the extinction of the Ottoman dynasty, the Gerays could be the only alternative to replace them on the former's throne. ${ }^{2}$

The Crimean Khanate was a major power in Eastern European politics, which continued this status even after it had become a vassal state of the Ottoman empire. Notwithstanding the supreme suzerainty of the Ottoman sultan, the Crimean Khanate retained almost all vestiges of sovereignty, such as having its own ruling dynasty, distinct state structure and traditions, establishing diplomatic relations with other states, minting its own coins, etc. For the most part of its existence, the Crimean Khanate was by no means politically, psychologically or militarily inferior to Russia: it always considered itself the direct continuation of the empire of the Golden Horde which had ruled over the Russian lands for two centuries. It was not until 1700 that Muscovy ceased to pay the Crimean Khans the annual tribute going back to the times of the Golden Horde. ${ }^{3}$ The military might of the Crimean Khanate was more than able to stave off the Russian advance towards the south well into the second half of the eighteenth century.

In 1783, after 15 years of war and anarchy, the Crimean Khanate was destroyed and its territories were annexed to Russia. Following the annexation, within a short time all male members of the Geray dynasty who belonged to the direct line of succession left or were forced by the tsarist rulers to leave the Crimea. Thus deprived of their homeland, the Gerays took refuge mostly in the Ottoman empire, settling either in the Rumelian provinces ${ }^{4}$ or in the north-western Caucasian territories of the sultan. Many of those who went to the north-western Caucasus eventually dwelled among the Nogay or Adyge ('Circassian') tribes there, not necessarily under direct (or even indirect) Ottoman authority. ${ }^{5}$ The departure of the Gerays from the Crimea also signalled the beginning of the great exodus of their people too: in the course of almost a century and a half, hundreds of thousands of Crimean Tatars would emigrate to the Ottoman empire in large waves.

The majority of Gerays in the Ottoman empire settled in those parts of Rumelia which constitute today's Bulgaria and Turkish Thrace. As matter of fact, since at least the sixteenth century the Ottomans had granted large estates to the members of the Geray dynasty in these provinces. Though never severing their ties with the Crimea, hundreds of Gerays lived in Rumelia. They had included those who had previously been deposed from power in the Crimea and had been awaiting better days. Actually, the Gerays in Rumelia had constituted a handy pool for the Ottomans from which 
they could select the best ones to send to rule the Crimea. With the demise of the Crimean Khanate, the numbers of the Rumelian Gerays were complemented by many newcomers from the Crimea.

Apart from their historical status in the Crimea, Gerays in Rumelia played important roles on the local scale long after the fall of the Crimean Khanate. With their unquestionable credentials and the deep-seated respect they enjoyed, they were sui generis notables who had a certain place in the socio-political balance of power in Rumelia. Almost all Gerays in Rumelia practically functioned as the administrators of the regions surrounding their mansions. Besides serving in political and administrative capacities, the members of the Geray pedigree in the Ottoman empire undertook military roles as well. Particularly during the Ottoman-Russian and Ottoman-Habsburg wars in the last quarter of the eighteenth century, several Gerays assumed commanding posts in the Ottoman army, displayed distinction, and many of them were wounded, taken prisoner, or killed in action.

As a matter of fact, during the first half of the nineteenth century, there were more than 100 male Gerays residing in various parts of Rumelia. ${ }^{6}$ One of the important Geray mansions in Rumelia was in the village of Vyrbitsa near Şumnu (Shumen) in what is today eastern Bulgaria. It is known that at least since the second half of the seventeenth century the Gerays had established themselves in Vyrbitsa. ${ }^{7}$ Arslan Geray Sultan, the prince who resided in Vyrbitsa in early $1740 \mathrm{~s},{ }^{8}$ later became the Crimean Khan in the years 1747-56 and 1767. ${ }^{9}$ For more than two centuries the line of Gerays, descended from Arslan Geray Khan, resided in Vyrbitsa and the county of Gerlobad, which included several villages other than Vyrbitsa.

Though none of them became khans, the offspring of Arslan Geray Khan also rose to prominence in the Crimea or in Rumelia. His son Mesud Geray Sultan became the qal̆gay under Qırım Geray Khan. ${ }^{10}$ Mesud Geray Sultan lost his life while fighting against the Russians in defence of the Ottoman fortress of Yergögü (Giurgiu) in 1771 during the Ottoman-Russian War. ${ }^{11}$ Mesud Geray Sultan's sons, especially Cengiz Mehmed Geray Sultan and Bahadir Geray Sultan, played important roles in Rumelia. Although both of them stood out due to their gallantry during the Ottoman-Russian War of 1787-92, during the following decade they were actively involved in the tumultuous power struggle in Rumelia and were outlawed by the Ottoman government. Cengiz Mehmed Geray Sultan was especially prominent in the Rumelian events in 1799-1803 as an ally of Osman Pazvandoğlu, the famous Rumelian power magnate and the unruly pasha of Vidin. Pardoned and rehabilitated by the sultan, Bahadir Geray lived to participate in the Ottoman-Russian War of 1806-12. In 1807, he was given the command of the Tatar troops of the Ottoman empire with the title of qal $\breve{g} a y$, notwithstanding the fact that the Crimean Khanate no longer existed for almost a quarter of a century. ${ }^{12}$ Bahadır Geray Sultan fought with distinction in the war until he was taken prisoner by the Russians. ${ }^{13}$

Bahadir Geray Sultan was succeeded by his son Mesud Geray Sultan in Vyrbitsa. ${ }^{14}$ The latter was born sometime during 1810 s. ${ }^{15}$ His mother was Hürmüz Hanım. ${ }^{16}$ Apparently, Mesud Geray Sultan inherited the post and role of his father at a young age. Like his forefathers, he enjoyed considerable influence and authority in the region. It was he who built the great mansion of the Gerays in Vyrbitsa in 1835-36 which would remain standing until the 1970s. ${ }^{17}$ At time of the outbreak of the Ottoman-Russian War in 1853, Mesud Geray Sultan, who was known to his contemporaries as 'the Lame Sultan', was residing there. 
Mesud Geray Sultan was a controversial figure, having plenty of friends and foes at both local and central levels. Some sources described him as an oppressor and exploiter of his subjects, while others praised him as the benevolent protector of the local people, especially the Bulgarians. ${ }^{18}$ The latter group of sources describes him as a selftaught surgeon and an altruistic man who cured the local sick and wounded. ${ }^{19}$

A lawsuit against him provided clues about his personality and local standing. In 1852 , he, together with his younger brother Mehmed Geray, was sued by a number of locals under the charges of severely oppressing and terrorizing the people of the 48 villages in the county of Gerlobad, to the extent of burning their houses and even committing murder. He was also accused of embezzling money from the locals, having a dungeon underneath his mansion complete with 'punitive instruments' such as fetters and shackles, and of keeping the wife of a Gypsy man as his mistress. The suitors demanded not only the appropriate legal action against these Gerays, but also their banishment from the region forever. The incriminating evidence against the Geray Sultans in Vyrbitsa appeared strong enough, as witnesses included not only a number of local villagers and notables, but it was clearly backed by the provincial executive and judicial officials, including the county head himself. ${ }^{20}$

The Geray Sultan had no less an impressive company of local supporters. When Mesud Geray appeared in the courtroom to face the charges, 30 to 40 of his backers were also there to testify on his behalf. During the process, when Mesud Geray Sultan smiled at the accusations, the county head Hüseyin A $\breve{g a}$ slapped him on the face, and later Mesud Geray, together with his brother Mehmed Geray and all their supporters, were imprisoned for two months. ${ }^{21}$ However, the response of Mesud Geray to this public indignity was to appeal to the higher authorities and set in motion his connections in Istanbul. Thus, the whole case was investigated by the Supreme Council of Judicial Ordinances (Meclis-i Vâlâ-yı Ahkâm-l Adliyye). The Geray Sultan totally denied the gravamen and all other accusations. He stated that all these were fabrications and a plot organized against him by the county head Hüseyin Ağa and the kadı (judge) Karamanzâde Hasan Efendi. The public humiliation meted out to him by the county head, who had cursed and slapped him, was unacceptable for anybody, let alone someone of his pedigree, as a result of which shame he could not live in his house for six months. Mesud Geray Sultan asserted that he had been unjustly kept in jail for 50 days and during this time his farm had been left unattended. Moreover, the county head had forcibly removed his caretakers and workers from his farm and all his animals had been left to die. ${ }^{22}$

The Geray Sultan defended himself against the charges by stating that the people were forced or lured to testify against him, that all the charges were slanderous, that his 'dungeon' was meant only to keep captured highwaymen and other criminals in the region before handing them over to the authorities, that the woman allegedly kept by him was actually an orphan who had been raised in the Geray mansion as a foster child, etc. Mesud Geray's position was supported by the testimonials of several local dignitaries and people who described him as a pious and honest man devoted to charitable work and accused the officials of being the true oppressors and explained their iniquitous deeds. ${ }^{23}$

Finally, in October 1852, the Supreme Council ruled, accepting the innocence of Mesud Geray and condemning the local officials and dignitaries who incriminated the Geray Sultan. Hüseyin Ağa, the county head of Gerlobad, and the kadı Hasan 
Efendi were not only dismissed from their posts, but both were sentenced to be exiled to Varna for a year. In the verdict, Mesud Geray Sultan was only warned that he should not imprison any culprits or accused persons in his personal mansion and that he should hand them immediately to the law enforcement authorities. ${ }^{24}$

In such a case involving hundreds of litigants, defendants, and eyewitnesses with conflicting arguments and interests, it is very difficult to ascertain the veracity of the claims and counterclaims. There can be no doubt that personal influences and connections played a weighty role throughout the conduct of this case. Putting aside the question whether Mesud Geray was actually an innocent victim of slanderous accusations, or whether he was able to manipulate the process of the trial to some degree to produce such a favourable conclusion to the case, one might suggest that he must indeed have had some powerful connections and supporters in Istanbul as well as in his 'domains'.

At the very time Mesud Geray was suffering with his personal problems, the Ottoman capital was being hard pressed by far more serious matters. The 'Eastern Question' once more evolved into an international crisis which diplomatic efforts were unable to resolve. In June 1853, Russian troops occupied the Ottoman Danubian Principalities and on 4 October 1853 the Porte declared war on Russia. By the end of October, fighting between the Ottoman and Russian armies had started on the Danubian front. On 27 and 28 March 1854, Britain and France also joined the war on the side of the Turks.

Soon French and British troops set sail to the Turkish Straits to join the Ottoman armies. In May 1854, large numbers of French and English forces began to be deployed at Varna against the invading Russians, together with the Ottoman army which was already in the area. The commanders-in-chief of all three armies also came to Varna to discuss their joint course of action; it became clear by summer that this would involve a landing on the Crimean peninsula.

While all these preparations were going on in Varna and the surrounding areas on the Şumnu road, Devna and Aladin, Mesud Geray Sultan was residing in the village of Vyrbitsa, not far from the Allied headquarters. Sometime during summer 1854, he established contact with the French army stationed at Varna and conveyed his wish to join the French army and participate in the war. It is not known why Mesud Geray, an Ottoman subject, appealed to the French rather than the Ottomans. In reply to Mesud Geray, General Vansky, the French chief executive officer in Varna, addressed him 'Son Altesse' in reference to his royal background, and stated that the Geray's request was accepted and that he was assigned to the French troops in the Crimea with the rank of major. ${ }^{25}$

The French at Varna must have been informed about the credentials of Mesud Geray Sultan and the significance of his pedigree. It is obvious that, preparing their landing on Crimean soil, the French intended to utilize the historical memory and influence of the Gerays over the Crimean Tatars in the person of Mesud Geray. In any case, the fact that Mesud Geray sailed to the Crimea with the commander-in-chief of the French army, Marshal Achille Le Roy Saint-Arnaud, in early September $1854^{26}$ testified to the importance the French attached to Mesud Geray Sultan.

On 13 September 1854, when the Allied soldiers began to land near Kezlev (in Russian: Yevpatoriia), Mesud Geray Sultan and the Polish émigré officer Wilhelm Tokarski were sent to the town as Allied emissaries to talk to the inhabitants, 
a majority of whom were Crimean Tatars. ${ }^{27}$ It seemed natural that they were chosen to communicate with the locals, as the former naturally spoke the language of his compatriots, while the Pole was fluent in Russian.

Addressing a sympathetic Crimean Tatar crowd which they met, Tokarski declared that Russian rule was over and now they had to obey the Allied high command. He said, 'From now on, the Crimea will not belong to Russia, but it will become free and independent under the protection of France'. ${ }^{28}$ Notwithstanding the fact that these unauthorized words had little to do with official French policies, the crowd was happy.

Having learned about his presence, special enthusiasm was displayed to Mesud Geray Sultan. ${ }^{29}$ The crowd raised him on their shoulders. The exultant people also kissed the hands and uniforms of those Turkish soldiers who were present there. Mesud Geray, together with Tokarski and a large number of Crimean Tatars, walked to a mosque (in all likelihood the Khan's Mosque - Han Camii) and offered a thanksgiving prayer. Later, both Mesud Geray Sultan and Tokarski resided in the house of the Karaim merchant Kaskaçı in Kezlev. ${ }^{30}$

During his time in the Crimea, Mesud Geray stayed in Kezlev. In the absence of sufficient evidence, the details of his activities in the Crimea are yet to be clarified. Moreover, the surviving documents give contradictory information about his role there. He had arrived in the Crimea embedded in the French troops, and had no official bearing with the Ottoman army, though he was an Ottoman subject. Yet the Russians, if not also the Crimean Tatars, considered him the official representative of the Ottoman empire or even an Ottoman pasha. ${ }^{31}$ As for the British, they gave no countenance to the service of this Crimean Tatar prince in the Crimea from the very start, ${ }^{32}$ though at times they had to cooperate with him to a certain extent.

Apparently, Mesud Geray undertook some sort of administrative work in Kezlev, or rather played the role of an intermediary between the Allied forces and the native Crimean Tatars. During the first days of the Allied occupational administration in Kezlev, Mesud Geray helped the three Allied commanders stationed there in maintaining order in the city and forming a local police force. ${ }^{33}$

In September and October 1854 the limited number of Allied forces were in a precarious situation in Kezlev. As the main body of the Allied armies were marching southwards toward Sevastopol, during the first weeks of their occupation, there were only a few hundred Allied troops in the town, which was defenceless and lacking any fortifications. ${ }^{34}$ It was also imperative to bring cattle and grain into the town from the hinterland, and to safeguard them from the attacks of the Cossacks. In the face of the severe lack of Allied troops in Kezlev, such critical patrolling duty could only be entrusted to the local Crimean Tatars. Against all odds, this hurriedly organized Crimean Tatar militia performed a very good job. The British governor of Kezlev, Captain Saumarez Brock, reported to Vice-Admiral J.W.D. Dundas:

We had now hitherto been little molested by the enemy, who had given us time to strengthen our position by ditches, palisades, \&c.; but their videttes began to show themselves, and occasionally skirmishes took place with our mounted Tatars, who evinced a great deal of courage and determination in their conduct before the enemy. The Tatar arms consisting of scythes set on poles, and rude fir lances, with knives for spear-heads, and some few flint muskets; but with only 
simple means they managed to save many of their flocks and herds from being carried off. ${ }^{35}$

The number of Crimean Tatar militia in Kezlev soon reached 800. ${ }^{36}$ Apparently, Mesud Geray played an important role in enlisting people into this militia. Yet some reports from both the Russian and English sides alleged that his conduct was far from flawless. In a Russian intelligence report, it was stated that he had not only demanded money from the people while enlisting them into the militia, but had also asked the militia to bring him the booty from the enemy. He allegedly dealt very harshly with the locals. ${ }^{37}$ Another Russian intelligence note claimed that at times even a high-ranking Turkish official (probably Mustafa Pasha, the Ottoman fleet commander) from the anchored fleet had come to the town and reproached Mesud Geray for leading the Crimean Tatars astray and ordering them to plunder. ${ }^{38}$

Captain Brock was no more sympathetic in his comments about Mesud Geray: '[He was] so utterly corrupt and villainous in his transactions with the natives, that he was reflecting great discredit on the allied cause, and pillaging all those peaceful inhabitants who looked to us for protection' ${ }^{39}$ According to Captain Brock, that was why Mesud Geray's activities in the Crimea did not last long and, by a joint decision of the British and French commanders of Kezlev, he was sent back to Turkey. ${ }^{40}$ By late October he was in Istanbul. ${ }^{41}$

Mesud Geray's activities in the Crimea, however, were reflected in a very different way in the Ottoman documents. In a common testament of the three Allied commanders in Kezlev, including Captain Brock himself, addressed to the Ottoman authorities, it was stated that Mesud Geray had 'resigned from his job' and he was highly praised for his services to the Allied forces and for establishing the security of the region around Kezlev. ${ }^{42}$ Perhaps this document might have been prepared in order to send Mesud Geray away from Kezlev as soon as possible in an honourable fashion. Another document bearing the signatures of several Crimean Tatar dignitaries, elders, clerics, and other men of stature from the Kezlev region (with more than 220 signatures) testified to their contentment due to the presence of the Allied troops there and to the activities of Mesud Geray. They also pledged to sacrifice their lives for the sake of the Ottoman state and to serve its army. ${ }^{43}$ The testimony of a Crimean Tatar volunteer militiaman after his emigration to the Ottoman empire also provides somewhat different information from the English and Russian reports. Here, the ex-militiaman attested that he had commanded a 12-man mounted platoon in Kezlev under Mesud Geray and that they had captured large numbers of sheep from the enemy. They had submitted these sheep to Mesud Geray Sultan and they had been used to provision the volunteer militia. ${ }^{44}$

Whatever the true nature of Mesud Geray in the Crimea might have been, we know that he was eventually awarded the order of Légion d'honneur by the French. ${ }^{45}$ In April 1855 the Ottomans also decorated him in a similar way 'for his commendable service in the Crimea' ${ }^{46}$ Having returned from his ancestral homeland, Mesud Geray settled back in his mansion in the village of Vyrbitsa. There he seems to have continued the typical life of a Geray in Rumelia. He was still prestigious and respected. His matrimonial stories involving a local Bulgarian girl (or girls) became popular tales which long survived him in the region. ${ }^{47}$ In the meantime, he continued to receive the special salary granted to the members of the Geray family by the 
sultan. ${ }^{48}$ An incident which took place possibly some time during 1860 s made him a very popular figure among the local Bulgarians. A number of Bulgarian rebels, fleeing from the Ottoman security forces, took refuge in the mansion of Mesud Geray Sultan. When the Ottoman officers asked the Geray Sultan to surrender them, the latter categorically refused to do so on the grounds that they were his guests. Cognizant of the Geray Sultan's authority, the officers could only bow respectfully and leave. ${ }^{49}$

Mesud Geray died on 11 January $1869 .^{50}$ After the independence of Bulgaria, his son Mehmed Ali Muhyeddin Geray was elected to the Bulgarian parliament. His descendants emigrated to Turkey in successive waves during the twentieth century. ${ }^{51}$

The brief venture of Mesud Geray in the Crimea was more than an interesting slice in the life of a Crimean Tatar prince in Rumelia; it had important implications for the outlook and plans of the Porte, as well of its Allies, regarding the future of the Crimea. At first sight, the dispatch of a member of the Crimean royal dynasty to the Crimean war front might make one think of the existence of a scheme involving the restoration of the former Crimean Khanate. Yet there is no evidence of such a scheme. Did the Allies have any plans for the future of the peninsula on which they fought so bitterly? In fact, the occasion of the seemingly unnoticed affair of Mesud Geray leads us to inquire more broadly into the war aims and designs of the Allies concerning the future of the Crimea, going far beyond the personal story of this provincial Crimean prince.

First and foremost, the Crimean peninsula was chosen as the place for the strike against the Russian empire on purely military, strategic, and psychological grounds. The choice of the Crimea was not related to a particular plan by the Allies concerning the future of this land, though a few statesmen would indeed cherish such ideas as events unfolded.

When Britain and France entered the war on the side of the Ottoman empire, they had no intention of simply continuing the 'Ottoman war' against Russia, that is, supporting the Ottomans in line with the concerns and aims of the latter. Rather, each country had its own objective in fighting against Russia on the regional and global scale. Therefore, while Allied political and military circles began to mull over the nature and direction of joint military action against Russia, they were guided by their own different strategic aims. The Ottomans were primarily concerned with recovering the occupied lands and stabilizing their position against Russia, rather than dreaming about conquests. Britain was thinking of disabling Russia to hinder its southward expansion at the expense of the Ottoman empire which thereby threatened the British interests. Bonapartist France was trying to make the best of this crisis to raise its prestige and weight in the European, if not global, political arena. None of the Allies had any large-scale invasion of Russia in mind. Conscious of their naval supremacy, the Allied powers thought of dealing a hard blow to Russia which would win prestige for them and cripple Russia, forcing it to accept a favourable peace. ${ }^{52}$

British military and political circles considered Sevastopol, which was a fortified port at the south-western corner of the Crimean peninsula and the bastion of the Russian Black Sea Fleet directed against the heart of the Ottoman empire, as the most suitable target among few other alternatives (e.g. the Russian Black Sea forts adjacent to Circassian lands, Polish lands). ${ }^{53}$ As early as November 1853 the French were also 
contemplating an attack on Sevastopol and the destruction of the Russian fleet, among other options. ${ }^{54}$ By March 1854, both sides agreed in favouring an operation whose aim was the capture and destruction of Sevastopol. ${ }^{55}$

On 9 May 1854, the Emperor Napoleon III ordered his commander-in-chief, Marshall Saint-Arnaud, to look for advantageous ground to fight a battle against the advancing Russians on the Danubian front; if they did not advance, then to attack the Crimea. ${ }^{56}$ The Times, on 15 June 1854, succinctly explained the intentions of many leading figures in London by stating that Britain had to teach the Russians a lesson they would not forget. The London newspaper wrote, 'We hold, therefore, that the taking of Sebastopol and the occupation of the Crimea are objects which would repay all the cost of the present war, and would permanently settle in our favour the principal questions now in dispute'. ${ }^{57}$ Finally, the British cabinet sanctioned an amphibious operation on the Crimea on 27 June $1854 .{ }^{58}$ The French, after some hesitation to determine the purpose of the Russians, as well as to ascertain the attitude of the Austrians, also agreed formally to attack Sevastopol. ${ }^{59}$ However, the Ottomans, who had long been fighting against the Russian armies on the Danubian front, were more interested in pushing back their adversaries there. The Ottoman commander-in-chief, Ömer Pasha, was in favour of an offensive in the direction of Bessarabia. ${ }^{60}$

Thus, while contemplating a descent on the Crimea, the designs of the Allied powers were almost purely military in nature and included hardly any plans for the political future of the peninsula. That the Crimea was inhabited mostly by the Crimean Tatars was certainly noted by the Allies, who counted the former's potential sympathies as among the favourable considerations in designating the Crimea. The presence of a common belief in Britain about the disaffection of the Crimean Tatars against Russia and sympathy towards Turkey (together with some doubts) was also voiced at the British Parliament on 24 July $1854 .{ }^{61}$ At the beginning of the Crimean campaign The Times stated:

In the Crimea there is great reason to suppose that if the inhabitants are kindly treated, paid for their produce, and made to understand the object of the expedition, they will be more ready to sympathize with the invaders than to assist their former masters. The Turkish division of the army will serve as a link between the Mahomedan population and the European forces; for although nearly 70 years have elapsed since the Turks were compelled to evacuate their last position in the Crimea, the country has not lost its Tartar character, and it was thought by no means impossible that with a little assistance from the other side of the Black Sea the population would be disposed to rise against the Russian yoke. $^{62}$

One should also remember that, at the same time, the concept of 'Tartar' (Tatar) did not always have pleasant connotations in Britain. The word 'Tartar' was used frequently to denote the 'barbarian' or 'Asiatic' nature of the Russians, or it was used synonymously with the latter. ${ }^{63}$

To be sure, especially before the actual start of the hostilities, a number of highranking British figures had the idea of impeding the southward expansion of the Russian empire by means of establishing some kind of a buffer zone of friendly states in the Black Sea region and the Caucasus. Such a 'buffer zone' would certainly include 
the Crimea, which would be detached from the Russian empire. A few unpublicized statements by some of the highest British dignitaries at the earliest stages of the war are examples of these schemes. Such were the 'beau ideals' of Lord Palmerston, then the British home secretary, which he expressed to the cabinet in a memorandum on 19 March 1854, shortly before the British declaration of war against Russia. There, he mentioned several proposed radical territorial changes on the map of Russia and even central Europe, which included the 'return' of the Crimea to the Ottoman empire. ${ }^{64}$ Palmerston would repeat and elaborate these 'possibilities' of changing the post-war European map to Lord Clarendon, the British secretary of state for foreign affairs, in his letter dated 6 April 1854. There he wrote:

we want to engage Sweden to join us and we mean to offer her Aland and possibly Finland. We want Prussia to join us, and the Results of the war might raise the Question whether some Part of the German Provinces of Russia on the Baltic might or might not be added to Prussia, in Exchange for the Polish Part of the Duchy of Posen in the Event of a Restoration of the Kingdom of Poland; and such a Restoration, not under a Russian Prince, would probably be the best security for the Independence of Germany. We want Austria to join us, and it may be doubtful whether it would be advisable to shut out the Possibility of an arrangement by which Austria might have the Principalities and the mouths of the Danube so as to cut off Russia from Turkey, Austria giving up in exchange her Italian Provinces, and Turkey being indemnified by the Crimea, the Eastern Shore of the Black Sea and Georgia. ${ }^{65}$

'All these arrangements [which might] at present be justly regarded as Day Dreams', as Palmerston admitted, were after all possible measures to induce the benevolence, if not the alliance, of critical European states at the beginning of the war. In those days, Palmerston also cogitated over the possibilities of crippling Russia and creating a buffer zone around it to render it harmless. He wrote:

The best and most effectual security for the future Peace of Europe would be the severance from Russia of some of the frontier territories acquired by her in later Times, Georgia, Circassia, the Crimea, Bessarabia, Poland and Finland. If these were taken from her she would still remain an enormous Power, but far less advantageously posted for aggression on her neighbours. ${ }^{66}$

Certainly, Palmerston's schemes were not the accepted war aims of Britain. In fact, Palmerston seriously differed from Lord Aberdeen, the then prime minister, who thought that attempting to impose the ideas of the former on Russia would plunge Europe into another Thirty Years War ${ }^{67}$ Many others in Britain also dismissed Palmerston's schemes as leading to a long war. ${ }^{68}$

The British ambassador to the Ottoman empire, Viscount Stratford de Redcliffe, also cherished the idea of creating a series of buffer states in the Black Sea area. Such a settlement, in Stratford's words, would be something

by which the course of the Danube would be free, the [Danubian] Principalities extended to the Black Sea, and released from Russian protection, Circassia 
restored to independence under the suzerainete of the Porte, the Crimea established in a similar manner, the Black Sea opened to foreign ships of war, and Poland restored in the limits recognized by the Congress of Vienna. ${ }^{69}$

During the first month of the Allied landing on Crimean soil when the capture of Sevastopol seemed imminent, Palmerston became more impassioned about realizing his 'beau ideals'. His letter to Clarendon a week before the Allies landed in Crimea gave a quite detailed view of his desired version of territorial changes after the victory:

[T] he Crimea might be given up to Turkey and this would on the whole be the best. We must hope that the war will not End without the Russians being driven out of Georgia and Circassia and the Sea of Azof, and if Turkey got Possession of those Quarters the Crimea would link on well enough. Then again we may reasonably look to wresting from Russia the Mouths of the Danube on the other Side of the Black Sea. If the Turks had the Command of the Black Sea, and if their Fleet was put into good order which it might easily be when no longer cooped up in the Bosphorus, they might be well able to hold the Crimea against the Russians as they have held the Line of the Danube and its Fortresses.

Such an arrangement would be the only real Security for Constantinople.

As to making the Crimea an independent State that is of Course out of the Question; it is too small a Country for such a State of Existence.

An adverse Critic might say catch and kill your Bear before you determine what you will do with the Skin, but I think our Bear is as good as taken. ${ }^{70}$

The secretary of state for foreign affairs was at variance with Palmerston in regard to the fate of the Crimea however. Writing to Lord John Russell, the prominent Whig politician and the leader of the House of Commons, on 9 September 1854, Clarendon stated: 'Palmerston wants to give [the Crimea] to the Turks; but that will never do, and Stratford in his letter to-day deprecates in the strongest terms adding one inch of territory to the Sultan's dominions. ${ }^{\text {,71 }}$

After the first Allied victory on Crimean soil, that is, the Battle of Alma, Palmerston's Bear seemed even closer to being caught. On 27 September 1854, a confident Clarendon wrote to Stratford considering the possible and preferable options following the seizure of Sevastopol. Clarendon was in favour of retaining this celebrated naval base not only to provide a suitable shelter for passing the winter (as appears to have been the opinion of Napoleon III too). He was against the idea of demolishing the base once it was captured, since such an act would have implied that the Allies were intending eventually to return Sevastopol to Russians, thereby losing its value as a bargaining chip in the future peace negotiations. Once the city was securely in their hands, the Allies could deliberate quietly how to dispose of that territory. The British secretary of state was also concerned about the fate of the Crimean Tatars:

We should however be delivering up to [the tsar's] tender mercies the Tartars who have (as appears to be the case) committed themselves in our favour - wherefore 
this latter point - I have the strongest feeling, for if we have accepted the services of these poor people and thereby exposed them to Russia's vengeance, they must not be deserted [underlined in the original]. ${ }^{72}$

He did not clarify the way in which the Crimean Tatars should not be betrayed.

For Clarendon, the retention (at least for the time being) of Sevastopol would be 'the best counterpoise to Austrian occupation of the Principalities'. As the British and French would have permanent quarters on the Black Sea, the command of Constantinople, and the mouths of the Danube, a position which would suggest the possibility of stirring up the Hungarian and Slavic subjects of the Habsburg Kaiser, it 'would wholly extinguish any project of mediation that may be lurking in the Austrian mind'. He was also troubled by the possibility of the emergence of a quarrel between the British and French allies, as Napoleon might change his mind and decide to keep Sevastopol for himself if the naval port was not demolished. If possible, Clarendon would prefer not to restore the Crimea to Russia, but he displayed his reservations by stating 'the Crimea cannot shift for itself and I don't see what Power we can establish there capable of withstanding Russian vicinage'. Like Stratford, he was also against 'adding an inch to existing Turkish territory'. The final settlements of the questions of Georgia and Circassia were to be complicated too, because the British should look to check the Russian advance towards Persia and India without, however, committing to engagements beyond their capabilities. On that account, he believed that spending the winter securely in Sevastopol and gaining time to think about the disposal of the Crimea would be the best solution. ${ }^{73}$ Incidentally, the hopes for establishing winter quarters in Sevastopol would not be realized as the Russian fortress was to hold out for a year. The next day Palmerston repeated his views to Clarendon on these issues:

Now as to the Crimea, what is the Thing most to be avoided. Evidently the restoration of that Country to Russia. The Possession of the Crimea gives to Russia the Command of the Black Sea, and a Predominance over Turkey, you may blow up the Sea Defences, and the Land defences, you may burn the Magazines and destroy the Docks, but you cannot alter the Geographical Position or the Topographical arrangement of Sebastopol, and in spite of any Engagements to the Contrary, Russia would soon reestablish Sebastopol as a formidable naval Station. She would not want works of Defences. The Natural Harbour would be enough. Her building Station would be Nicholaeff or some other Place. All she would want at Sebastopol would be Stores and Magazines; and her Fleet lying there in Safety would be ready to threaten every Part of the Black Sea....

But if the Crimea is not to be restored to Russia how is it to be disposed of? Why should it not be given to Turkey? Turkey it is said could not keep it. I doubt this. The Turks have shewn themselves good Hands at defensive warfare. If Turkey had Sebastopol she would be the dominant naval Power in the Black Sea, and if her navy was got into good order which it then might be by cruises and exercise in the Euxine she could secure the Crimea against Invasion by Sea, while the Isthmus of Perekop might be so fortified as to enable them to defend it by Land. 
Moreover if the Crimea were Turkish the Tables would be turned against Russia, Odessa would be exposed and Constantinople secure. Then too we may I hope look to driving the Russians out of Georgia and Circassia, and that would make the Possession of the Crimea by Turkey more easy and more secure. ${ }^{74}$

Palmerston was strongly in favour of the Allied armies wintering in the Crimea and keen not to destroy the defences of Sevastopol when the city was captured by the Allies. Apart from any other considerations, as had already been argued by Clarendon, the destruction of these defences would mean that the Allies were determined to restore Sevastopol to Russia after the war. ${ }^{75}$

His influence then and later throughout the Crimean War notwithstanding, Palmerston was certainly in no position to tailor the British policy alone. His stance over the future of the Crimea was not shared by others, including his then political allies. For instance, Russell's suggestion of a post-war treaty between the belligerents, dated 1 October 1854, stipulated that the pre-war boundaries of Russia and Turkey should be preserved. A special article on the plans for the Crimea stated that the peninsula might be restored or not restored to Russia, in case it would be restored the fortifications at Sevastopol should be destroyed. ${ }^{76}$ Aberdeen too preferred that, when captured, the fortifications of Sevastopol be immediately razed and the city evacuated. ${ }^{77}$

At this time the issue of the future status of the Crimea was raised by Edouard Drouyn de Lhuys, the French foreign minister, in his conversation with Henry Wellesley Lord Cowley, the British ambassador to France. As Cowley informed London, Drouyn de Lhuys discussed the question whether to keep or abandon Sevastopol when it was captured, if occupied whether the Allied occupation should be confined to the city or to be extended over the Crimea, and whether the defences of Sevastopol would be destroyed or maintained. The French foreign minister was in favour of occupying Sevastopol, and while he said that the matter of extending the occupation to the rest of the Crimean peninsula would be a decision depending on strategic measures to be made by the commanders-in-chief of the Allied armies, he made it clear that he would like to see the whole of the Crimea occupied. He saw three options for disposing of the Crimea:

It might be restored to Russia. It might be again placed under the rule of the Sultan. Or it might remain in the possession of the French and English. In neither of these cases would there be any necessity for preserving the fortifications. If the Crimea was restored to Russia it must be restored shorn of that which gave Russia such preponderance in the Black Sea. If it was to be again placed under the rule of the Sultan, it would not be prudent to place the Porte in possession of a Place of such military importance. As the Russian fleet would be destroyed the Porte would have nothing to fear from outward attack and would have no need of defences as now existed. Lastly, if the Crimea was to remain in the hands of the French and English, as they would have nothing to fear from maritime aggressions it was clear that they could do without impregnable fortifications. For all these reasons [Drouyn de Lhuys] should prefer to see the defensive works of the Crimea destroyed at once. ${ }^{78}$

In his reply to the French foreign minister, Cowley, among other things, said that he contemplated only two of the three contingencies 
as possible with regard to the Crimea - that it should be restored to Russia, or replaced under the authority of the Porte, for as France and England had declared that in engaging in this war they renounced beforehand all advantage to themselves they could hardly keep possession of the Crimea or any part of it without placing themselves in contradiction to this declaration. ${ }^{79}$

The Emperor Napoleon III was also disturbed by the same question. In this regard, Marshal Jean-Baptiste Philibert Vaillant, the French minister of war, wrote to General François Certain de Canrobert, who had become the French commander-in-chief in the Crimea after Saint-Arnaud's death, on 10 November 1854. The emperor was considering keeping the Crimea by maintaining a sufficient force there. However, Vaillant differed on this subject. Together with all problems of maintaining and provisioning an army of 80,000 to occupy the Crimea, the marshal questioned the prudence of not being able to use them in Germany on the Rhine in case of any uncertainty. At any rate, the Crimea needed to be strongly fortified if it was to be defended against the Russians. If the peninsula were returned to Russia eventually, all these would have been wasted. Vaillant also discussed the options of making the Crimea an independent state or handing it to the Ottoman empire. The marshal believed that the independence of the Crimea would not last more than three months and Russia would regain it, together with the undestroyed fortifications of Sevastopol. The worst choice would be to turn the Crimea over to the Ottomans, who were not capable of defending such a gift; they would either be beaten by Russians, or sell the Crimea to the latter. According to Vaillant, therefore, if Sevastopol were to be seized, the best solution would be to destroy all its defences, to tear down its fortresses, and to fill up its port with earth from its hills, and then to evacuate the Crimea, maintaining a force of 25,000 in Istanbul for operations in the Black Sea and the Caucasus the following year. $^{80}$

At that time, Drouyn de Lhuys approached Veliyeddin Rifat Pasha, the Ottoman ambassador in Paris, bringing forward the same issue in a quite different manner and context than he had previously discussed with the British ambassador. On 14 November 1854, Veliyeddin Rifat Pasha wrote to Istanbul that he had been received by Drouyn de Lhuys, who had told him that when the whole of the Crimean peninsula was captured by the Allies it would not be appropriate to put it under French or English rule, while its 'return' to the Ottoman empire would be the correct path of action. In such a case, the French foreign minister had stated, since such a land could not be governed as an ordinary province, it should be ruled by a special viceroy similar to the case in Egypt and the ideal candidate for that post was Ömer Pasha, the Ottoman commander-in-chief. ${ }^{81}$

When this information was conveyed to Ömer Pasha, he politely refused to consider that possibility, arguing that he was merely a soldier and not suitable to govern such a critical land, and in any case, at the moment the most urgent task for the Allies was capturing the fortress of Sevastopol; anything else could be resolved after the peace. ${ }^{82}$ One could argue that the Ottoman commander-in-chief simply did not desire to jeopardize his current position for an uncertain proposal. Expounding upon this to the Sultan Abdülmecid, Mustafa Reşid Pasha, the grand vizier, curtly dismissed the matter by stating that though the return of the Crimean peninsula to the Ottoman empire would be something 'exceedingly desirable', its settlement would be contingent on the 
outcome of the ongoing war and the issue of the governorship of the Crimea could be discussed only then. A reply in this vein was to be sent to the Ottoman Embassy in Paris. This line of action was also sanctioned by the sultan. ${ }^{83}$

The proposal of Drouyn de Lhuys to the Ottoman ambassador hardly reflected the official position of France. There is no indication that a similar opinion was ever shared by Napoleon III or the French government or even they were aware of such a proposal. This proposal should be understood in the context of the time it was uttered. By then, even after the victories at the battles of Alma (20 September 1854) and Inkerman (5 November 1854), the Allied hopes of a prompt capture of Sevastopol had already been frustrated. The undermanned Allied commanders had realized that a quick victory was not in sight. In the meanwhile, the bulk of the Ottoman army was still on the Danubian front. Therefore, the transfer of the large Ottoman army of Ömer Pasha to the Crimea became essential to the French and British, who insistently urged for that. ${ }^{84}$ As the reluctance of Ömer Pasha to leave the Danubian front was well known, it appears that Drouyn de Lhuys must have made his vague (and most likely unauthorized) proposal about the 'return of the Crimea to the Ottoman empire if whole of it would be captured and Ömer Pasha be given its governorship' as a bait both to lure the Porte and Ömer Pasha in person to agree to the swift transfer of troops to the Crimea. The sincerity of Drouyn de Lhuys was most questionable. It is noteworthy that, only a few days before he received the Ottoman ambassador, he had read to Cowley a report by Vincent Count Benedetti, the French chargé d'affaires in Istanbul. There, Benedetti accused Ömer Pasha of never having had any serious intention of following the Russians on the Danubian front, as he dreaded an encounter with them on open ground. ${ }^{85}$

There was at least one other similar case in which Drouyn de Lhuys made an 'unauthorized' promise to Ömer Pasha. Soon after his abortive proposal to the Ottoman ambassador, on 22 November 1854, he cabled to the French consul general in Bucharest urging the latter to apply pressure on Ömer Pasha (obviously to relieve the Allied forces in the Crimea) to attack Russians on the Pruth at all costs. In order to induce Ömer Pasha to advance, Drouyn de Lhuys pledged to support him with two imaginary French divisions without having any intention of doing so. In any case, Ömer Pasha would not be fooled and refused to move. ${ }^{86}$ Drouyn de Lhuys admitted this incident to Cowley, to the astonishment of the British ambassador. ${ }^{87}$ Learning this, Clarendon commented:

I am really shocked and ashamed that this announced French movement towards Bessarabia should have had no foundation at all. I never believed it would take place but I thought it must have been intended, but the consequence is that Omer Pacha hesitates to comply with the requisition of Raglan and Canrobert to go with 18 Battalions to the Crimea until he knows whether his doing so will interfere with the Emperor's plan of campaign. I hope he will have been told by telegraph to comply forthwith and that may furnish the French Government with a loophole out of their lie. ${ }^{88}$

Vaillant also disapproved of Drouyn de Lhuys' clumsy wile, writing to him that too much finesse would bring harm and 'It's the biter bit'. ${ }^{89}$

The war proved to be a far longer one than the Allied powers initially hoped. The fortress of Sevastopol staunchly resisted and it tied the Allied armies down for almost 
a year. Throughout all this time, the Allied hold on the Crimea was confined to a thin strip of coastal land around Sevastopol (which was not even fully encircled) and Kezlev. Every day of the dragging war cost all the belligerents dear, not only because of direct combat casualties, but also due to the epidemics, harsh living conditions, and insufficient care. The financial burden was also swelling fast. On the other hand, especially in Britain and France, the public was sensitive to the events on the front which it was able to monitor far more closely and quickly than any of the previous wars. All these developments certainly affected the war aims and designs of the Allied powers, including those about the future status of the Crimea.

In the meantime, while the fighting was going on, indirect peace talks were also taking place in Vienna with Austrian mediation on the basis of the famous 'Four Points' which had been formulated by the two western powers and Austria back in August $1854 .^{90}$ Apparently, as the focus of the negotiations was on the 'Four Points', the future of the Crimean peninsula was hardly raised during the negotiations which began on 15 March 1855. As a matter of fact, two months before the Vienna talks had started, in January 1855, the Austrian Emperor Franz Josef had privately given his word to Prince Aleksandr M. Gorchakov that Austria would not support the Third Point which impaired the honour and sovereignty of Russia in the Crimea and on the Black Sea coast. ${ }^{91}$ Naturally, such a word of honour would not only effectively impede the discussion of the secession of the Crimea during the talks, but would also eventually frustrate the peace talks as the Third Point was of foremost importance to the Allies.

The instructions given to Âlî Pasha, the Ottoman foreign minister and plenipotentiary at the negotiations, by Sultan Abdülmecid in March 1855 were characteristic. It was clear in these instructions that upholding the 'Four Points' in the Ottoman interests was the cardinal issue. There, the preservation of the pre-war territorial integrity of the Ottoman empire as well its suzerainty over Wallachia, Moldavia, and Serbia were considered of utmost importance.

Within this context, there was mention of the independences of the Crimea, Circassia, and Dagestan in the instruction. It was stated that, if any changes in the status of these lands were put on the table, then the question of 'creating Muslim governments out of the Crimea, Circassia, and Dagestan under the official protection of the Ottoman empire and giving Georgia an appropriate status' might be raised. ${ }^{92}$ Although 'delivering the Crimea, Circassia, and Dagestan from the oppressive claw of Russians and reshaping the status of Georgia would be most preferable from the perspective of politics, humanity, and the glory of the Powers', it was admitted in the instructions that the progress of the war had not reached such a point. ${ }^{93}$ Given the conjecture, eventually the Ottoman delegation in Vienna deemed it necessary to keep silent about these matters. ${ }^{94}$ It was clear that the Porte had no serious strategy on the subject of the status of the Crimea and Caucasus which were considered only as bargaining chips or counterweights in defending other issues which were thought to be of critical importance. No further case is known when these matters were discussed by the Ottoman authorities until the signing of the peace treaty.

The future status of the Crimea, especially its 'return' to the Ottoman empire or its becoming independent, seldom became a matter of discussion in the Allied high circles until the fall of Sevastopol on 8 September 1855. To be sure, Palmerston, who had become the prime minister in February 1855, was still insistent in his desire to 
force Russia to cede the Crimea to the Ottoman empire and Bessarabia to an autonomous Moldavia (the latter being under Ottoman suzerainty and under the protection of the Allied powers including Austria), to restore the independence of Circassia, and to evacuate the territories which it had conquered in the Caucasus during the last 25 years. Palmerston was conscious that Russia would not accept these conditions. In that case, which he very much wished, the peace talks in Vienna would collapse and the war continue. He was sure that the victories the Allies could win in the Crimea by the end of 1855 would compel Russia to accept these terms. ${ }^{95}$ There were also members of the British Parliament who were curious about the fate of the Crimea. On 8 June 1855, Spencer Walpole asked the government: 'Is England to hold the Crimea? Is France to have the Crimea? Will you restore Mahomedanism in that part of Europe, or will you give the territory back to the Tartar population?' 96

The fall of Sevastopol on 8 September 1855 was a breakthrough in the Crimean War. The year-long siege of Sevastopol and the great bloodshed for its sake had made this city seem the prime target of the entire struggle. Once it was captured, it appeared that the Allies, having already seized Kerch and Yenikale back in May 1855, would easily occupy the rest of the Crimean peninsula. Such an assumption once more raised the question of the way the Crimea would eventually be disposed of. In the great euphoria of the victory at Sevastopol, a number of British statesmen, primarily Palmerston and Stratford, advocated continuing the war until Russia was brought to heel. Writing to Clarendon soon after receiving the good news from the Crimea on 13 September 1855 , Stratford urged for pursuing the victory 'before we can satisfactorily return the sword to its scabbard'. He was still insistent on creating a buffer zone of independent neutral states to confine Russia. ${ }^{97}$

For Clarendon, however, at this stage of war Sevastopol or the whole Crimean peninsula was primarily 'an excellent commodity for the peace market' ${ }^{98} \mathrm{He}$ thought that not returning the Crimea to Russia would be the best security against the latter's aggression, though he was not comfortable about who should have the Crimea, in terms not only of military and political practicalities, but also of Christian moral principles:

England and France even if they had to put a veto upon territorial acquisition would not consent to either holding the Crimea and if the Turks were to get it they could not defend it. I know however that this is a favourite scheme with many persons, but setting aside all other objections I think we could hardly displace a Xtian Power in order to establish a Mahomedan Power there. ${ }^{99}$

At any rate, he was sure that the Russians would never yield the Crimea to the Ottoman empire or to anyone. ${ }^{100}$

Another British personage, George Cornwall Lewis, the financial secretary to the Treasury, was thinking in the same vein. Upon the fall of Sevastopol he expected that the whole Crimean peninsula would be in the hands of the Allies by November 1855 . Yet in that case he thought it would be either controlled by Britain and France jointly or handed over to the Ottoman empire. He wondered how the first option could work. He was especially troubled by the second option, as he questioned whether this would 'be a measure in the interests of civilization, or would Turkey be able to hold if France and England were otherwise occupied? ${ }^{101}$ 
In the weeks after the fall of Sevastopol, Count Karl Ferdinand von Buol, the Austrian foreign minister, prepared a peace initiative which would give Austria the role of a mediator. Certainly, the initiative had been launched after receiving positive signals from the belligerents. Russia had indicated its assent to Austrian mediation after losing Sevastopol. The Ottoman side had suggested its readiness to negotiate. There had also been promising signs from Paris. ${ }^{102}$ Count Buol disclosed his plan in his secret talks with Baron François Bourqueney, the French minister to Austria, in late September 1855. The Austrian initiative was based on the Four Points of the previous year which were strengthened in view of the changed circumstances and also modified to suit Austrian interests. While talking to Bourqueney regarding his initiative, Count Buol revealed that he had also been expecting and even rationalizing an Allied move to capture the rest of the Crimea. The Austrian foreign minister was confident that the Allies would obtain possession of the peninsula and until then it would be useless to think of peace. Once the Allies took the peninsula, 'they would be justified in keeping the Crimea if they pleased'. ${ }^{103}$

Britain was informed of the Buol-Bourqueney talks through Cowley in Paris. Although the British would not reject the Austrian initiative outright, its conditions were considered very unsatisfactory. Not surprisingly, Palmerston was insistent on continuing the war. He agreed with Clarendon that 'Russia has not yet been beat enough to make peace possible at the present moment'. ${ }^{104}$ Still, he believed that Buol's conditions for peace could be made acceptable with certain amendments. Before the peace the Allies should take the Crimea, Georgia, and Circassia and they could be captured easily by October $1856 .{ }^{105}$ Clarendon was also convinced that these lands ought to be taken and that this was possible within a year. Unlike Palmerston, however, who considered the cession of these border lands from Russia as an essential to permanently cripple Russia, the British secretary of state for foreign affairs saw it as a means to pressure Russia with conditions which it would be unlikely to accept:

Of course as Bourqueney says Russia will try to get rid of all She dislikes in a Treaty of Peace, but this would apply equally to great conditions as to small and the more we are able to impose the longer Russia will be in shaking them off and the more time Europe will have to prevent Her. ${ }^{106}$

It is notable that at this time Queen Victoria would comment that 'We ought to be prepared to contemplate the erection of the Principalities and of the Crimea into independent States'. 107

For the inclusion of the Crimea in any post-war scheme, it was imperative that all of it should be occupied by the Allies. However, the fall of Sevastopol was not followed by an all-out invasion of the Crimean peninsula, if for no other reason, because this very costly war had already been too prolonged and now the differences between the objectives of the Allied powers were becoming clearer. The French, who bore the brunt of the military burden in the capture of Sevastopol and who comprised by far the largest part of the Allied armies in the Crimea were quite content with the glory of this accomplishment. To be sure, soon after the victory at Sevastopol and clearly driven by the success, Napoleon III was reckoning on an easy seizure of the whole Crimea by forcing the Russians to retreat. He then deemed the possession of the peninsula as a material guarantee in the peace negotiations. ${ }^{108}$ 
Yet General Aimable Pélissier, the commander-in-chief of the French forces in the Crimea, was very much averse to any forward movement. The French troops were not expecting any greater glory in the Crimea than they had already achieved and were more concerned about the notion of a possible future campaign on the Rhine. ${ }^{109}$ Accordingly, on 17 October 1855, Napoleon III passed on to Cowley Pélissier's view that attacking the Russian positions after Sevastopol was more difficult than taking Sevastopol itself. The emperor told Cowley that the Allies might be forced to retire to the French base (at Qamıs Bay on Cape Khersonesos) after completely destroying Sevastopol and to re-embark the greater part of their armies either to return home or to attack elsewhere, holding only Qamış Bay, Kezlev, and Kerch on the Crimean peninsula. ${ }^{110}$ Napoleon III was indeed confused about what to do in the Crimea. He thought the partial evacuation of the Crimea the best choice among many evils and now saw no advantage in taking the peninsula completely. For him, the results which the Allies prescribed at the outset of the war had already been attained by the capture of Sevastopol and they would be made binding by the peace treaty. Therefore, the French emperor concluded, the '[Allied] operations for the future in the Crimea need only be defensive supported by a strict blockade'. ${ }^{11}$

Having learned about Napoleon's opinion, Clarendon, no longer a staunch proponent of the secession of the Crimea from Russia, protested vigorously in his letter to Cowley in Paris. He was confident that by only a moderate display of determination and activity the Allies might still strike a decisive blow and obtain the results which were the essential preliminaries to peace. On the other hand, he wrote, 'the effect of withdrawing altogether from the Crimea any large portion of the Allied armies and bringing them home to France and England would be most disastrous'. In that case, nobody would believe that the Allies had reached their objective and Russia might lay claim to victory; even Austria, whose benevolence was bound to Allied military successes, would oscillate towards Russia. All these would make an honourable peace further off than ever. Still, he let the French emperor know that the British had no desire to force their views on Napoleon. ${ }^{112}$

Eventually, Napoleon III gave up the idea of withdrawal and for the time being kept the French troops in the Crimea in deference to his allies. Nevertheless, the French troops were not keen to stay there. ${ }^{113}$ In view of the ever-increasing costs of war and the feeling of having already achieved glorious successes by then, the emperor was becoming loath to continue fighting. Besides, Napoleon III's advisers were strongly pressuring him for peace. Count Alexandre Walewski, the new foreign minister, was the champion of this stand and an ardent supporter of Buol's initiative, even when the emperor did not desire Austrian mediation. ${ }^{114}$

By mid-November 1855, the talks between Buol and Bourqueney proceeded with the enthusiastic backing of Walewski to produce a plan for an ultimatum to Russia by Austria which included the earlier Four Points and a fifth one which ensured the belligerents the right to put forward particular conditions over and above the Four Points. The change from the Four Points of the previous year was that now a small piece of territory in the southern part of Bessarabia was to be ceded to Moldavia (which was under Ottoman suzerainty) by Russia and the Black Sea was to be neutralized. ${ }^{115}$ All these terms were far softer than the British would contemplate and did not include any territorial concession on the part of Russia except for the above-mentioned Bessarabian land which was added to the plan to suit Austrian interests. 
Clarendon was uncomfortable not only with the terms, but also with the fact that they were concocted between France and Austria without Britain, not to mention his lack of trust in regard to the Austrians. Nevertheless, he anticipated a Russian refusal, which hopefully would result in urging Napoleon to press on with the war. ${ }^{116}$

Palmerston was much more indignant. On 21 November 1855 he wrote to Jean Gilbert de Persigny, the French ambassador in Britain: 'The English nation would be delighted with a good peace which would assure the objects of war; but rather than be dragged into signing a peace with inadequate terms, she would prefer to continue the war with no other allies than Turkey, and she feels wholly able to sustain the burden. ${ }^{117}$

The bombastic tone of this letter could hardly veil the fact that it would not be plausible for Britain to continue the war without France. Moreover, a day before, the British cabinet had already voted to accept the ultimatum to Russia prepared by Austrians and the French. Queen Victoria was also in favour of going along with the proposal of the ultimatum and urged for moderation. ${ }^{118}$ Thus, Palmerston was forced to yield and prepare the British amendments to the ultimatum. His and Clarendon's strategy was to insert such clauses in the ultimatum as to ensure its rejection by the Russians. ${ }^{119}$ The two British statesmen only agreed to negotiate over the proposal of the ultimatum lest the French withdraw from the war. They hoped that the Russian rejection of the ultimatum would lead to Austria's participation in the war. Though their amendments to the proposed articles of the ultimatum were generally quite moderate, they demanded a special condition for a discussion of the status of the peoples in Russia's provinces on the eastern coast of the Black Sea, having in mind Circassia and Georgia. They were sure that Russia would reject such a condition. ${ }^{120}$

However, Buol, supported by Walewski, refused to include this special condition in the ultimatum. Eventually, in order not to lead the Austrians withdraw from the peace process altogether, Palmerston and Clarendon were compelled to give their approval to the ultimatum without the special condition. In fact, they had contemplated noting, before the armistice, that what they had approved were only the Austrian conditions, not the British ones. Thus, the ultimatum was presented to Russia without the special conditions about Circassia and Georgia on 28 December $1855 .{ }^{121}$

A month before this, on 27 November 1855, the strategic Ottoman fortress of Kars, after a long siege, had surrendered to Russia. Although Russia was otherwise very war-weary and desperate to accept the terms of the ultimatum as the basis of the peace conference on 16 January 1856, the victory at Kars had offered it a critical object of barter on the negotiation table. To the chagrin of Palmerston, the process leading to the signing of the peace treaty in Paris now began.

By then, any rhetoric or thought on the secession of the Crimea from the Russian empire had long vanished among the British statesmen. It was notable that the abovementioned special conditions were confined to the lands east of the Black Sea, i.e. Circassia and Georgia, and did not include the Crimea. Even Stratford would abandon designs for the secession of the Crimea. He wrote to Clarendon on 3 February 1856, three weeks before the opening of the Congress of Paris, that he did not know what could be done with the Crimea if severed from Russia. For him, its restoration to Russia 'without its fleet and fortifications, laid open to a free commercial intercourse, and placed under the surveillance of consular dragons ... would offer the maximum of advantage to us and our allies'. ${ }^{122}$ 
Accordingly, the Treaty of Paris returned the Allied occupied parts of the Crimea to the Russian empire and did not include any clauses directly referring to the Crimean Tatars. ${ }^{123}$ During the peace conference in the French capital, when the British brought to the table their 'special conditions' about Circassia and Georgia, these could not be sustained in the face of the lack of will among the other Allies, including the Ottomans, to continue the war for their sake. ${ }^{124}$

Throughout the Crimean War, among the Allied powers Britain, or rather certain British dignitaries, displayed the greatest interest in and devised schemes for the future of the lands on which they fought. Such schemes involved the eventual cession of the Crimea from the Russian empire in some fashion. Palmerston and - to a certain extent - Stratford were champions of this outlook. Their considerations did not stem from their special concern about the land of Crimea or its inhabitants per se. These two critical figures of the Crimean War in Britain were determined to cripple the Russian empire and to stop its southward expansion by means of depriving it of its colonial holdings in the Black Sea-Caucasus region. This could be done either by creating a buffer zone of independent and friendly states or by turning these lands over to Ottoman rule. Only then could Russia be rendered harmless to its southern neighbours and thereby to global British interests. Especially Palmerston remained true to these convictions and considered any peace terms which were short of permanently incapacitating Russia and which did not force it to tangible territorial concessions would be a waste of blood and money. In fact, Palmerston's designs concerning the confinement of Russia went far beyond the cession of the Crimea and Caucasian lands and involved an intricate reshaping of the map of most of Europe. However, in spite of the apparent public support for the Crimean War and the prevalent anti-Russian atmosphere, it is not possible to say that Palmerston's stance on these matters, particularly concerning the Crimea, was shared by many in the Parliament. The aspirations of Palmerston such as restoring the independence of Poland or at least wresting the possession of the Crimea from the Russian empire were considered 'of a very extreme character', by his political rival the Conservative Benjamin Disraeli, and not only by the latter. ${ }^{125}$

The dragging on of the war for another year after the landing on the Crimea, with ever-increasing material and human costs, certainly played a critical role in jettisoning the grandiose schemes and lofty ideas of Palmerston, who in that period was in troubled waters at home as well. In any case, the realization of Palmerston's designs was contingent upon a major defeat of Russia, which would bring it to heel. Its value as a naval base, as well as the psychological importance attached to it by the Allies notwithstanding, for Russia the mere fall of Sevastopol would mean the loss of a peripheral campaign, not a sufficiently major defeat for it to be coerced to concede such terms. ${ }^{126}$ Moreover, any claims on the Crimea needed to be substantiated by seizing virtually all of it, while under the given circumstances Palmerston's Britain was not likely to invade the entire Crimean peninsula without the military contribution of France, which in turn was so obviously reluctant to undertake this task. No doubt, the loss of Kars also seriously weakened the bargaining hand of Palmerston at the Paris Congress for demanding concessions in the Black Sea area.

Some British statesmen, in the first place Clarendon, demanded the Russian secession of the Crimea or other lands such as Circassia or Georgia not for its own sake, but rather as a trump card to pressure Russia to make concessions on other matters. 
Clarendon was thinking of keeping the Crimea for some time during the war also to affect the political stance of Austria and to make an impression upon it so that the Habsburg monarchy would not lean towards Russia. Hardly any of the British politicians, including Palmerston and Stratford, who favoured the cession of the Crimea from Russia, considered the independence of the Crimea viable. For them, in that case Russia would recapture the peninsula at the first opportunity. That was why Palmerston insisted upon offering the Crimea to the Ottomans, whom he thought - with British support - could manage to hold it.

Generally pleasant relations existed between the British troops and the local Crimean Tatar population on the occupied lands as far as daily affairs were concerned. Apart from that, the British interest in the fate of the Crimean Tatars was confined to a few humanitarian issues such as displaying limited concern about the care and transportation of refugees in Kezlev. Otherwise, they refrained from anything resembling a political commitment toward them. At any rate, as has already been shown, the British were keen not to have any involvement in the venture of Mesud Geray in the Crimea. Perhaps the last occasion when the British showed any concern about the Crimean Tatars was during the Allied evacuation of the Crimea following the Treaty of Paris. In an interview with Prince Aleksey Fyodorovich Orlov, the Russian plenipotentiary to the Paris Congress, Clarendon raised the issue of the Crimean Tatars who had collaborated with the Allies. Thereupon, Orlov promised Clarendon 'that no harm should befall the Tartars in the Crimea who had taken part with the Allies, and particularly those who had been engaged in the British Service'. ${ }^{127}$ This last incident might be considered as clearing the conscience of the British, and personally that of Clarendon, who had once said that the Crimean Tatars must not be abandoned to Russian vengeance.

The French side was much less interested in the secession of the Crimea from the Russian empire. When, during the initial phase of the Allied landing on the Crimea, a few French dignitaries questioned the possibilities of what to do with the peninsula, they concluded that any independence given to it would not be long-lasting. It appears that the alternative of turning the Crimea over to the Ottoman empire only became a subject of discussion when Drouyn de Lhuys abortively attempted to use it as a device to manipulate Ömer Pasha.

To be sure, it was the French who had recruited Mesud Geray while they had camped in Varna. However, although this prince of the ex-Crimean Khanate was enlisted and taken to the Crimea together with the French troops, there is nothing to indicate the existence of any grandiose plans involving the revival of the Crimean Khanate on the part of Bonapartist France. After all, Mesud Geray Sultan was neither the most senior nor the most influential figure among hundreds of members of the Geray pedigree who were spread mostly through Ottoman Rumelia. His being chosen by the French was purely coincidental, as he happened to reside near the French headquarters at Varna. In any case, it was Mesud Geray Sultan who offered his services first. All the evidence suggests that he was taken to the frontline only with the thought that he might be of some practical use in rallying the support of the local Crimean Tatars, and nothing more than that. When the task delegated to him was thought to be completed or his deeds were found to be unsatisfactory, the French chose to send him back in an honourable fashion. On the other hand, although the French occupational forces in the Crimea were generally on good terms with the local 
Crimean Tatars, their record of conduct was not always flawless. There were occasional cases especially involving the French zouaves who committed pillaging and violence against the locals. Hearing about such cases, Marshal Saint-Arnaud ordered that these crimes be severely punished. ${ }^{128}$

After the capture of Sevastopol, the French lost their enthusiasm for fighting for further conquests and did not wish to continue to spill their blood for what they deemed to be the objectives of others (the British). ${ }^{129}$ Therefore, restoring the Crimea to Russia and returning home became the policy of Bonapartist France.

As for Austria, its primary concern was securing the Danubian principalities and the mouth of the Danube from the Russian threat as well as increasing its own influence there. Adding a piece of territory from the Russian-held Bessarabia to Moldavia would serve this purpose. The Habsburg monarchy was not interested in the secession of the Crimea from Russia, considering that such territorial concessions on the part of Russia would jeopardize the latter's conceding land in Bessarabia. Besides, the Austrian Kaiser gave his word to maintain the territorial integrity of the Russian empire in the Black Sea area (meaning obviously with the exception of that Bessarabian land).

Given the memories of their suzerainty over the Crimea only 80 years before and their religious, linguistic, and cultural kinship with the Crimean Tatars, the Ottomans were expected to harbour certain intentions about the political future of the Crimea. Yet, with the outbreak of the war, the primary concern of the Porte was turned to averting the Russian aggression by whatever means and not going beyond that. The mounting popular sentiments aside, ${ }^{130}$ the outbreak of war hardly inspired any revanchist ambitions at the Porte concerning the Crimea or elsewhere. As stated above, the choice of the Crimean peninsula as the place of the Allied strike was decided not upon the suggestion of the Ottomans, but by that of the French and British commanders-in-chief.

The Ottoman war aims did not contain a plan or agreement about the political future of the Crimean Tatars even in the case of a victory. The Turkish soldiers of the Ottoman troops were certainly in contact with the Crimean Tatars (after all they were essentially speaking the same language) who viewed them with an unmistakeable sympathy. In late 1854, the Ottoman commander-in-chief Ömer Pasha asked the Porte to donate grain for some 30,000 Crimean Tatar refugees in Kezlev who were then suffering from starvation. He also proposed to make use of the able-bodied ones by arming them. Sultan Abdülmecid granted the requested aid the following month. ${ }^{131}$ In any case, the recruitment of the Crimean Tatars to the militia had already been started by then. Indeed, the Ottomans, like the other Allies, did cooperate with the local Crimean Tatars on practical and exigent matters during their occupation. However, there is no evidence of systematic attempt by the Ottoman army to activate the Crimean Tatar population as a whole either in the occupied territories or in other parts of the Crimea.

The official Ottoman outlook was reflected in Mesud Geray's case. To be sure, Mesud Geray had been brought to the Crimea without any Ottoman involvement. It is noteworthy that even when a Geray, one of the heirs of the Crimean Khanate and an Ottoman subject, was on Crimean soil, the Porte did not contemplate a political move concerning the Crimean Tatars or making use of the Gerays within the context of such a design. Although the Ottoman officers on the Crimean front were certainly aware of the activities of Mesud Geray in Kezlev, an analysis of the contemporary 
documents clearly indicates that Istanbul had no information or interest in the Geray Sultan's presence there. None of the several Ottoman documents dealing with the departure of Mesud Geray from the Crimea make any reference to his being a member of the Geray dynasty and his significance for the Crimean Tatars.

In the document which was submitted to Mesud Geray by the Crimean Tatar clergy, notables, and other influential members of the population of Kezlev, they declared that they were ready to sacrifice their lives for the sake of the Ottoman empire. ${ }^{132}$ Nevertheless, even such emotional documents did not seem to inspire political or military designs concerning the Crimean Tatars among the Ottoman authorities. In fact, that very remarkable document, which was also presented to the sultan for his perusal, was classified as a routine paper concerning the person of Mesud Geray and its contents did not raise any interest, or comment, at the Porte.

Prior to his departure from the Crimea, Mesud Geray wrote a letter affirming his loyalty to the Porte 'in the same way as his forefathers had displayed fealty and served in the past' (this being the only reference to his royal background, albeit an indirect one) and stating his wish to serve the Ottoman imperial army. Having received this letter through Omer Pasha, the office of the grand vizier questioned Mesud Geray's intentions, thereby indicating total ignorance of his activities or potential. The Porte decided not to give him a reply and it deemed, in the future, it might 'make use of his services in case they would be needed'. ${ }^{133}$ Such a 'case' would not take place during the war. For the Porte, the presence of Mesud Geray Sultan in the Crimea was nothing more than the voluntary service of a respectable Ottoman subject in the war. That was why he was later decorated. Otherwise, the Porte was totally unaware of, or indifferent to, the presence of a Geray in the Crimean war front.

During the Crimean War, the Porte was submerged in more urgent issues and immediate concerns than the political future of the Crimea. Its basic concern was to preserve the territorial integrity of the antebellum empire. There is no indication that the post-war status of the Crimea was ever brought forward by the Ottomans, either during the war or during the peace negotiations at Paris in 1856. Surely, the concern to regain Kars must have played a significant role in the Ottoman attitude in Paris. The Porte was very much satisfied when Kars was returned together with a piece of land in southern Bessarabia, not to mention the neutralization of the Black Sea, in exchange for the Allied evacuation of the occupied parts of the Crimea.

It should also be noted that during the Crimean War there was no Crimean Tatar society or any organized group to lobby the Allies for the societal interests of the Crimean Tatars either in the Crimea or abroad even at those conjunctures when they were likely to be heeded. Such groups of national/societal or political assertions would not emerge for another half a century. Their historical esteem notwithstanding, the members of the Geray pedigree in the Ottoman domains, including Mesud Geray, were practically in no position to represent, or stand up in the name of, the Crimean Tatar people. ${ }^{134}$ In fact, thousands of Crimean Tatar refugees, who were anxious that they would pay dearly for having displayed their sympathies to the Ottoman troops when their lands were returned to Russia, were accepted by the Ottomans as immigrants during and after the war. ${ }^{135}$

For the Ottomans, as was the case for the British and French, the Crimean War was a war on the Crimea, not one for the Crimea. The well-known African proverb, 'When elephants fight, it is the grass that suffers', proved to be bitterly true for the 
native people of the Crimea. The Crimean Tatars did not simply have to endure the ordeal of wartime destruction as well as the oppression by many tsarist officials who saw them as actual or potential traitors: as a consequence of the Crimean War, between 1855 and 1861, no fewer than 300,000 Crimean Tatars and Nogays were compelled to move to the Ottoman empire. In this great wave of Crimean Tatar emigration, large numbers of Tatars perished on the way or where they were settled. As for the Crimean Tatars who stayed in the Crimea, they became a minority, now under worse circumstances than before. In other words, in the Crimean War, regardless of whichever side won, the Crimean Tatars were destined to be the losers. This was to herald an even greater calamity for them some 90 years later. In the Second World War, the Crimea became a terrible battleground between Germany and the Soviet Union and in 1944 the Crimean Tatars were deported en masse from the Crimea upon Stalin's orders.

After the Crimean War, while the great exodus of Crimean Tatars from their homeland went on, the members of their historical dynasty continued to live in a scattered fashion mostly in Turkey (not to mention the Circassianized ones in the Caucasus). In fact, apart from its much broader international implications, Mesud Geray Sultan's brief 'visit' to the Crimea where his ancestors had ruled for centuries carried a symbolic meaning for the Geray dynasty. He seems to be the first Muslim Geray ever to set foot on Crimean soil again after the Russian invasion in 1783. This episode also appears to be the last involvement of the Gerays in any kind of political scheme in reference to their status as a royal dynasty, albeit in quite a vague fashion. Although in later decades a number of individual Gerays took up political posts in Turkey and in Bulgaria, ${ }^{136}$ their genealogical background would have no direct or even indirect bearing on their political identities and careers.

\section{Notes}

1. N. Dubrovin, Vostochnaia voina 1853-1856 godov. Obzor sobytii po povodu sochineniia M.I. Bogdanovicha (St Petersburg, 1878), p.41.

2. For such claims, see F.M. Emecen, 'Osmanlı Hanedanına Alternatif Arayışlar Üzerine Bazı Örnekler ve Mülahazalar', İslâm Araştırmaları Dergisi (İstanbul), No.6 (2001), pp.66-7, 69-75.

3. B.H. Sumner, Peter the Great and the Ottoman Empire (Hamden, CT, 1965), p. 22.

4. In this article, the concept 'Rumelia' was used to denote the Balkan territories of the Ottoman empire.

5. For the Gerays who were residing in the Caucasus, see H. Kırıml, 'Crimean Tatars, Nogays, and Scottish Missionaries. The Story of Katt1 Geray and other Baptised Descendants of the Crimean Khans', Cahiers du Monde russe (Paris), Vol.45, Nos.1-2 (Jan.-June 2004), pp.61-107.

6. A. Karaca, 'Giraylar (1440-1840)', Bir (Istanbul), No.7 (1997), pp.98-109.

7. S. Antonov, Tatarite v Bylgariia (Dobrich, 2004), p.45.

8. P. Miiatev, 'Potomki krymskikh Gireev i ikh gospodstvo v nekotoryh chastiakh Bolgarii v XVII-XIX vv.', Uchennye zapiski Instituta Slavianovedeniia, Vol.16 (Moscow, 1958), p.294.

9. H. Geray Sultan, Gülbün-i Hânân (Istanbul, 1870 [1287]), pp.103-5.

10. Ibid., p.109. The qal̆̆ay was the highest ranking person and state administrator after the khan himself in the Crimean Khanate. He would not only use the full authority of the khan in the absence of the latter, but he also enjoyed a vast power in normal times. By definition, he was a member of the Geray dynasty and usually one of the closest relatives of the khan.

11. Ş.F. Süleyman Efendi, Şemdânî-zâde Findıklılı Süleyman Efendi Tarihi. Mür'it-Tevârih, Vol.2.B (Istanbul, 1980), pp.74-5. 
12. T.C. Başbakanlık Osmanlı Arşivi, The Ottoman Archives of the Prime Ministry of the Republic of Turkey (BOA) (Istanbul), Cevdet-Hariciye, Dosya No. 103, Gömlek No. 5134; Cevdet-Hariciye, Dosya No. 82, Gömlek No. 4066.

13. BOA, Cevdet-Hariciye, Dosya No.100, Gömlek No. 4978.

14. The genealogical tree of the Gerays from the village of Vyrbitsa preserved by their descendants (Courtesy of İsmet Giray, the fifth generation descendant of Bahadır Geray Sultan, and Nicole Ferrari Kançal).

15. In a document pertaining to 1852 , he was described as 35 or 38 years old. BOA, Irade-Meclis-i Vâlâ, Dosya No. 250, Gömlek No.9150.

16. There was a local rumour that Mesud Geray's mother was from a wealthy Bulgarian family that had embraced Islam. Antonov, Tatarite v Bylgariia, pp.48-9. When Hürmüz Hanım died in 1850, in accordance with the Ottoman imperial tradition, half of her salary which she had been bestowed by virtue of belonging to the Geray dynasty, was granted to Mesud Geray Sultan. BOA, MVL, Dosya No. 326, Gömlek No. 73 .

17. B. Tsvetanov, 'Ogledalo na sveta', Nauka i tekhnika za mladezhta (Sofia), Vol. 22, No.1 (Jan. 1970), p. 47; the Turkish translation by Ayten Kılıç: 'Dünyanın Aynası Gerayların Vırbitsa'daki Sarayı', Emel (Ankara), No.223 (Nov.-Dec. 1997), pp.29-30; I. Giray, 'Atalarım Gerayların Bulgaristan'daki Sarayı ve Bazı Hatıralarım', Emel (Ankara), No.209 (July-Aug. 1995), p.18; H.-J. Kornrumpf, 'Zwei weniger bekannte islamische Denkmäler in Bulgarien', Südost-Forschungen (Munich), Vol.30 (1971), pp.295-6.

18. B. Mateev, 'Tsenni dokumentalni materiali na Vyrbishkite sultani Gerai', Istoricheski pregled (Sofia), Vol.12, No.2 (1956), pp.117-18; Miiatev, 'Potomki krymskikh Gireev', pp.297-8; Antonov, Tatarite v Bylgariia, p.48.

19. Giray, 'Atalarım Gerayların', p.18.

20. BOA, Irade-Meclis-i Vâlâ, Dosya No. 250, Gömlek No. 9150.

21. Ibid.

22. BOA, Irade-Meclis-i Vâlâ, Dosya No. 119, Gömlek No. 12.

23. BOA, Irade-Meclis-i Vâlâ, Dosya No. 250, Gömlek No. 9150.

24. Ibid.

25. Miiatev, 'Potomki krymskikh Gireev', p.296.

26. BOA, A.MKT.MHM., Dosya No. 64, Gömlek No. 66.

27. N.F. Dubrovin, Istoriia Krymskoi voiny i oborony Sevastopolia, Vol.I (St Petersburg, 1900), p.285.

28. Ibid., pp.285-6.

29. E. Colebrooke, Journal of Two Visits to the Crimea, in the Autumns of 1854 and 1855 with the Remarks on the Campaign (London, 1856), p.14; A.I. Markevich, Tavricheskaia gubernia vo vremia Krymskoi voiny po arkhivnym materialam (Simferopol/Aqmescit, 1994), p.14.

30. Dubrovin, Istoriia Krymskoi voiny i oborony Sevastopolia, p. 286.

31. Ibid., p.285. For some reason, this contemporary Russian document mentioned Mesud Geray Sultan not by his name but as 'Seyid İbrahim Pasha' or simply a Turkish pasha who was a descendant of 'Şah Geray' (sic). However, there is no doubt that the man at issue was Mesud Geray Sultan. An eyewitness report also called him as a 'Turkish pasha'. Markevich, Tavricheskaia gubernia, p.14. Another Russian intelligence report from the town, which named him correctly as Mesud Geray, described him as 'a man of no significance at all'. Rossiiskii gosudarstvennyi voenno-istoricheskii arkhiv [Russian State Military-Historical Archives - RGVIA] (Moscow), fond 846, op.16, d.5553, p.32.

32. Colebrooke, Journal of Two Visits to the Crimea, p.14.

33. Russian War, 1855. Black Sea. Official Correspondence (London, 1945), p.427.

34. Ibid., pp.426-7.

35. Ibid., p.428.

36. Dubrovin, Istoriia Krymskoi voiny i oborony Sevastopolia, p.289. In the following months the number of the Crimean Tatar militia in Kezlev on the Allied side was to reach around 2000. Golenkovskii, Zapiski deistviiakh Yevpatoriiskogo otriada v Krymu v 1854, 1855 i 1856 godakh (St Petersburg, 1856), p.4.

37. Dubrovin, Istoriia Krymskoi voiny i oborony Sevastopolia, pp.288-9. The person in this report was also described as 'the Turkish pasha', but without any doubt he was Mesud Geray.

38. RGVIA, fond 846, op.16, d.5553, p.32. This report mentions Mesud Geray by name.

39. Russian War, 1855. Black Sea. Official Correspondence, p.428. 
40. Ibid. Brock wrote that Mesud Geray 'was sent in a Turkish steamer back to Varna on 8 October 1854'. However, in an Ottoman document which contains the signatures of the three Allied commanders in Kezlev, including that of Brock, it was stated that since Mesud Geray had been brought to the Crimea by Marshal Saint-Arnaud he would be sent to Turkey in a French ship.BOA, Irade-Dahiliye, Dosya No. 309, Gömlek No. 19757. Since Mesud Geray arrived in Istanbul in late October, he must have departed from the Crimea some time later than 8 October.

41. BOA, A.MKT.MHM, Dosya No. 60, Gömlek No. 9; A.MKT.UM, Dosya No. 120, Gömlek No. 20.

42. BOA, Irade-Dahiliye, Dosya No. 309, Gömlek No. 19757.

43. Ibid.

44. BOA, Irade-Dahiliye, Dosya No. 369, Gömlek No. 24397.

45. 'Tatary i Cherkesy v Turtsii (Dva pis'ma byvshago Turetskago pashi)', Slavianskii sbornik (St Petersburg), Vol.2 (1877), p.50.

46. BOA, A.мKT.мHM., Dosya No. 64, Gömlek No. 66; A.MKT.NZD., Dosya No. 126, Gömlek No. 9.

47. Miiatev, 'Potomki krymskikh Gireev', p.297.

48. We have a petition of Mesud Geray about his salary (by virtue of his belonging to the Geray dynasty) pertaining to Sept. 1861. BOA, A.MKT.NZD., Dosya No. 365, Gömlek No. 23.

49. Giray, 'Atalarım Gerayların', pp.18-19.

50. BOA, BEO., Dosya No. 491, Gömlek No. 36777. Mesud Geray's salary was inherited by his son Mehmed Ali Muhyeddin Geray and his daughter Hürmüz Hanım. BOA, Irade-Dahiliye, Dosya No. 601, Gömlek No. 41888.

51. I am grateful to late İsmet Giray for this information about his family.

52. For a brief survey of the belligerents' war aims, see W. Baumgart, The Crimean War 1853-1856 (New York, 1999), pp.25-33.

53. A.W. Kinglake, The Invasion of the Crimea, Vol. II (London, 1888), pp.224-8.

54. 'Drouyn de Lhuys to Bourqueney, 26 November 1853', in W. Baumgart (ed.), Akten zur Geschichte des Krimkriegs, series 4, Vol. 1 (Munich, 2003), p.646.

55. 'Graham to Clarendon, 1 March 1854', Akten, series 3, Vol.2 (Munich, 2006), p.255; 'Palmerston to Clarendon, 4 March 1854', ibid., p.263.

56. Baumgart, The Crimean War 1853-1856, p.108.

57. The Times (London), 15 June 1854, p.8.

58. Kinglake, The Invasion of the Crimea, p.247.

59. Baron de Bazancourt, The Crimean Expedition to the Capture of Sebastopol, Vol.1 (London, 1856), pp.115-16, 122.

60. A.T. Gürel, 1853-55 Türk-Rus ve Müttefiklerin Kırım Savaşı (Istanbul, 1935), p.80.

61. Hansard's Parliamentary Debates: Third Series, Vol.CXXXV (London, 1855), col.627.

62. The Times (London), 26 Sept. 1854, p.6.

63. For example, Russia's expansion in Central Asia was defined as 'a Tartar invasion'. The Times, 7 Jan. 1854, p.6. In another article, it was claimed that a 'Tartar' was inherent in the Russian man and the latter's 'rude and savage' manners were attributed to the 'Tartar's moral and political deficiencies'. 'The Englishwoman in Russia', The Times, 5 Jan. 1855, p.8. Even at a later stage of the war when the Allied troops already had experiences of warm relations with the Crimean Tatar population in the Crimea, the perceived Russian threat was described as the 'Cossack and Tartar domination' who 'would trample down the civilization'. 'Guildford Agricultural Association', The Times, 14 Dec. 1855, p.10.

64. 'Memorandum by Lord Palmerston, 19 March 1854', cited in The Later Correspondence of Lord John Russell 1840-1878, Vol.2 (London, 1925), pp.160-61.

65. 'Palmerston to Clarendon, 6 April 1854', in Baumgart, Akten, series 3, Vol.2, p.322.

66. 'Palmerston's Memorandum, 26 May 1854', in ibid., p.416.

67. N. Rich, Why the Crimean War? A Cautionary Tale (New York, 1991), p.109.

68. A.D. Lambert, The Crimean War: British Grand Strategy, 1853-56 (Manchester, 1991), p.86.

69. Ibid., pp.109-10.

70. 'Palmerston to Clarendon, 7 September 1854', in Baumgart, Akten, series 3, Vol.2, pp.607-8.

71. 'Clarendon to Russell, 9 September 1854', cited in The Later Correspondence of Lord John Russell 1840-1878, Vol.2, pp.169-70.

72. 'Clarendon to Stratford, 27 September 1854', in Baumgart, Akten, series 3, Vol.2, p.644. For the original document: The National Archives (London), FO 352/37, Part A/1. 
73. Ibid., p.644.

74. 'Palmerston to Clarendon, 29 September 1854', in ibid., pp.649-50.

75. Ibid., p.650.

76. 'Russell's Memorandum, 1 October 1854', in ibid., p.651.

77. P.W. Schroeder, Austria, Great Britain, and the Crimean War (New York, 1972), p.205.

78. 'Cowley to Clarendon, 28 September 1854', in Baumgart, Akten, series 3, Vol.2, p.646.

79. Ibid.

80. C. Rousset, Histoire de la Guerre de Crimeé, Vol.1 (Paris, 1894), pp.355-7.

81. BOA, Irade-Hariciye, Dosya No. 116, Gömlek No. 5686.

82. Ibid.

83. Ibid.

84. Rousset, Histoire de la Guerre de Crimeé, p. 360.

85. 'Cowley to Clarendon, 7 November 1854', in Baumgart, Akten, series 3, Vol.2, p.742.

86. Rousset, Histoire de la Guerre de Crimée, p.362.

87. 'Cowley to Clarendon, 30 November 1854', in Baumgart, Akten, series 3, Vol.2, p.778.

88. Ibid., p.781.

89. Rousset, Histoire de la Guerre de Crimeé, p.363.

90. The first of these points was about Russia's renunciation of its protectorate over Wallachia, Moldavia, and Serbia, and their being placed under the guarantee of all the great powers; the second was about keeping the mouths of the Danube free of all obstructions; the third was about revising the 1841 treaty which closed the Turkish Straits to all states other than Russia and Turkey; and the fourth point was about the Russian relinquishment of its claims over the Christian Orthodox people of the Ottoman empire. There was also a fifth point which reserved the sea powers' right to raise further demands in accordance with the outcome of the war. Baumgart, The Crimean War 1853-1856, pp.17-18; Schroeder, Austria, Great Britain, and the Crimean War, p.193. Obviously, these conditions were far softer than the war aims contemplated by Palmerston and the people like him. At the time of the exchange of notes between the two western powers and Austria in August 1854, Palmerston was assuring Stratford that Britain would demand the secession of Georgia, Circassia, and the Crimea as her special condition under Point Five. Schroeder, Austria, Great Britain, and the Crimean War, p.194. Later, in November 1854, Palmerston would admit that the Fifth Point could hardly be stretched to include such demands like cession of these lands. Ibid., p.219.

91. Baumgart, The Crimean War 1853-1856, p.19.

92. A.F. Türkgeldi, Mesâil-i Mühimme-i Siyasiyye, Vol.1 (Ankara, 1987), p.341.

93. Ibid., p.344.

94. Ibid., p.60.

95. J. Ridley, Lord Palmerston (New York, 1971), p.445. The peace talks in Vienna were ruptured as Palmerston persuaded the French Emperor to reject the Austrian compromise proposal in June 1855. Ibid., pp.446-7.

96. Hansard's Parliamentary Debates: Third Series, Vol.CXXXVIII (London, 1855), col.1713.

97. 'Stratford to Clarendon, 13 September 1855', in Baumgart, Akten, series 3, Vol. 4 (Munich, 1988), pp.94-5.

98. 'Clarendon to Stratford, 17 September 1855', in ibid., p.114.

99. 'Clarendon to Albert, 20 September 1855', in ibid., p.121.

100. 'Clarendon to Russell, 26 September 1855', in ibid., p.147.

101. 'Lewis to W.R. Greg, 25 September 1855', cited in Letters of the Right Hon. Sir George Cornwall Lewis, Bart. to Various Friends (London, 1870), pp.299-300. Lewis reiterated these views in a letter to Sir James Graham. 'Lewis to Graham, 26 September 1855', in Baumgart, Akten, series 3, Vol.4, p. 149 .

102. Schroeder, Austria, Great Britain, and the Crimean War, pp.311-12.

103. 'Cowley to Clarendon, 13 October 1855', in Baumgart, Akten, series 3, Vol.4, pp.192-3. Buol's words were later reinterpreted by Count Alexandre Walewski, the French foreign minister, who said that what it had been meant was that Buol 'would not object to our keeping the Crimea for however an indefinite time, until we obtained the terms [of Buol's redesigned Four Points]'. 'Cowley to Clarendon, 17 October 1855 , in ibid., p.207.

104. 'Palmerston to Clarendon, 9 October 1855', cited in Marquis of Lorne, Viscount Palmerston, K. G. (London, 1892), p.175. In the same letter Palmerston wrote, among other binding clauses to be 
enforced on the Russians, 'if we get hold of the Crimea we ought well to reflect before we give it back to Russia. The Turks would be quite able to keep it, at all events till succour should arrive, especially if Russia had no war-fleet on the Black Sea'. Ibid., p.176.

105. 'Palmerston to Clarendon, 16 October 1855', in Baumgart, Akten, series 3, Vol.4, p.202.

106. 'Clarendon to Cowley, 17 October 1855', in ibid., p.204.

107. 'Victoria to Clarendon, 13 October 1855', in ibid., p.191.

108. 'Cowley to Clarendon, 15 September 1855', in ibid., p.108.

109. E. Hamley, The War in the Crimea (London, 1910), pp.294-6.

110. 'Cowley to Clarendon, 17 October 1855', in Baumgart, Akten, series 3, Vol.4, p.207.

111. 'Cowley to Clarendon, 22 October 1855', Ibid., p. 234.

112. 'Clarendon to Cowley, 24 October 1855', Ibid., p. 241.

113. J.B. Conacher, Britain and the Crimea, 1855-56. Problems of War and Peace (Houndmills, Basingstoke, Hampshire, 1987), p.126.

114. Rich, Why the Crimean War?, p.161.

115. Ibid., pp.169-70; Conacher, Britain and the Crimea, pp.144-6.

116. Conacher, Britain and the Crimea, p.147.

117. D. Southgate, 'The Most English Minister ...' The Policies and Politics of Palmerston (New York, 1966), p.385.

118. Rich, Why the Crimean War?, pp.171-2.

119. Schroeder, Austria, Great Britain, and the Crimean War, pp.329-30.

120. Rich, Why the Crimean War?, p.173.

121. Ibid., p.175.

122. 'Stratford to Clarendon, 3 February 1856', cited in S. Lane-Poole, The Life of the Right Honorable Stratford Canning Viscount Stratford de Redcliffe from his Memoirs and Private and Official Papers, Vol.2 (London, 1888), p.437.

123. However, Article V of the Treaty of Paris had a bearing on the Crimean Tatars at least indirectly. This article granted 'a full and entire amnesty to those of [the] subjects [of the belligerents] who may have been compromised by any participation whatsoever in the events of the war in favour of the cause of the enemy' and where it was 'expressly understood that such amnesty shall extend to the subjects of each of the belligerent parties who may have continued, during the war, to be employed in the service of one of the other belligerents' concerned, among others, those Crimean Tatars who had one way or another collaborated with the Allied forces in the occupied parts of the Crimea. J.C. Hurewitz (ed.), Diplomacy in the Near and Middle East, Vol.1 (Princeton, NJ, 1956), p. 154 .

124. Schroeder, Austria, Great Britain, and the Crimean War, p.359. The instructions handed over to Âlî Pasha for the Paris Congress did not include anything about the future of the Crimea. As for Circassia and Dagestan, it was expressly stated that, although it would be desirable if the peoples of these lands were given independence under the Ottoman suzerainty, the Ottoman delegation should not insist on these issues to the point of continuing the war. Türkgeldi, Mesâil-i Mühimme-i Siyasiyye, pp.379-80. The renowned Ottoman statesman and historian Ahmed Cevdet Pasha relates an account which was confided to him by an unnamed source. During the peace talks in Paris, when Clarendon asked Âlî Pasha to support him in raising the subject of the eastern Black Sea lands, the Ottoman plenipotentiary replied that those lands where of little interest to the Ottomans and they would only try to make a modicum of border rectifications in the region of Çürüksu (east of Batum). [A.] Cevdet Pasha, Tezâkir. 1-12, ed. C. Baysun (Ankara, 1991), pp.100-101.

125. Hansard's Parliamentary Debates: Third Series, Vol. CXLIII (London, 1856), col.1458.

126. Lambert, The Crimean War, p.87.

127. 'Clarendon to Palmerston, 20 April 1856', in Baumgart, Akten, series 3, Vol.4, p.1001.

128. Rousset, Histoire de la Guerre de Crimeé, p.166.

129. H.C. F. Bell, Lord Palmerston, Vol.2 (Hamden, Connecticut, 1966), p.137.

130. Ahmed Cevdet Pasha alluded to those warmongers in Ottoman society at the beginning of the crisis who talked about marching up to St Petersburg or Moscow or 'at least' conquering the Crimea! There were also panic-stricken others who predicted that the Russian army would be in Edirne within three months. However, according to Ahmed Cevdet Pasha the characteristic statesmen of the Tanzimat period, such as Mustafa Reşid Pasha, Âlî Pasha, and Fuad Bey (later Pasha) were hardly susceptible to such manifestations of extreme temperaments. Cevdet Pasha, Tezâkir, p.23. 


\section{H. Ktrtmlı}

131. BOA, Irade-Meclis-i Mahsûs, Dosya No. 4, Gömlek No. 140.

132. BOA, Irade-Dahiliye, Dosya No. 309, Gömlek No. 19757.

133. BOA, HR. MKT., Dosya No. 89, Gömlek No. 12.

134. Even in the case of the 'Circassians', i.e. the basically Adyge peoples of the Western Caucasus, in whose land, unlike the Crimea, the armed resistance against Russia was effectively going on and there were a number of communal leaders and chieftains claiming the allegiance of their compatriots, there was a similar problem. When Palmerston was mulling over the signing of a peace treaty between the Russia and the Circassians as a condition to be raised in the Paris Congress in 1856, he admitted that they did 'not quite know who could enter into an engagement on behalf of the Circassians'. Conacher, Britain and the Crimea, p.169.

135. For this wave of Crimean Tatar emigration, see H. Kırıml, 'Emigrations from the Crimea to the Ottoman Empire during the Crimean War', Middle Eastern Studies, Vol.44, No.5 (Sept. 2008), pp. 751-73.

136. The son of Mesud Geray, Mehmed Ali Geray became a member of the Bulgarian parliament (Narodno sybranie). Other Gerays were elected to the parliament of the Turkish Republic, notably Hüsamettin Giray (Istanbul, 1957-60) and Safa Giray (Istanbul and Balıkesir, 1983-99). The latter also served at various times in 1980s and 1990s as the minister of settlement and public works, minister of national defence, and minister of foreign affairs. 